RESEARCH NOTE

\title{
Novel Epoxy Butenolides from the Genus Hortonia
}

\author{
Rukmal Ratnayake', Shanal Gunasekera ${ }^{2}$, David Williams ${ }^{3}$, Raymond Andersen ${ }^{3}$ and Veranja Karunaratne Ka,1,* $^{2}$ \\ ${ }^{1}$ Department of Chemistry, Faculty of Natural Sciences, Open University of Sri Lanka, Sri Lanka \\ ${ }^{2}$ Department of Chemistry, University of Peradeniya, Peradeniya, Sri Lanka \\ ${ }^{3}$ Departments of Chemistry and Earth \& Ocean Sciences, University of British Columbia, Vancouver, B.C., Canada, \\ V6T $1 Z 1$
}

Received: 31/05/2018; Accepted: 27/11/2018

\begin{abstract}
Two new epoxy butenolides, (4S)-4-methyl-2-(9epoxy-11-dodecynyl)-2-butenolide and (4S)-4-methyl-2-((9Z)11-epoxy-9-dodecenyl)-2-butenolide were isolated from the dichloromethane extract of Hortonia angustifolia. They were characterized by means of Mass and NMR spectroscopic analysis. The latter compound showed moderate mosquito larvicidal activity against Aedes aegypti.
\end{abstract}

Keywords: Hortonia agnustifolia, endemic plant, dichloromethane extract, novel epoxy butenolides

\section{INTRODUCTION}

Sri Lanka is a plant biodiversity hot spot with $25 \%$ of its flowering plants being endemic. The independent diversity of Sri Lankan flora in comparison to peninsular India has led to speculation that during the continental drift, Sri Lanka may have experienced a higher degree of impoverishment, which would have contributed to the facilitation of speciation of new taxa on the other hand. Among the lower plants particularly among lichens, the recent reports of new species being discovered indicate that their diversity may be as prominent as the higher plants (Orange et al., 2001). Sri Lankan plants have been tested for biological activity with promising results (Hewage et al., 1997). In addition, the structural diversity among Sri Lankan higher and lower plants are typified by the discovery of, antioxidant alkaloids, (Puvenendran et al., 2008), compounds with iron sequestering ability (Kathirgmanathar et al., 2006; Karunaratne et al., 1992; Karunaratne et al., 2005; Tezuka et al., 1994; Bandara et al., 1990), and aromatic acids and ketones (Thadhani et al., 2012), all exhibiting a variety of biological activities.

The genus Hortonia is endemic to Sri Lanka and Dassanayake (1996) records three distinct species $(H$. floribunda Wight ex Arn., H. angustifolia (Thw.) Trimen and $H$. ovalifolia Wight). Some phytogeographers assume the genus Hortonia to have begun in Gondwanaland about 100-200 million years ago (Jayasekara, 1994). A noteworthy aspect of the chemistry of the genus Hortonia is the presence of compounds with five-membered rings highlighting their importance in natural products in nature (Piers and Karunaratne, 1984). We have previously reported the isolation of several biologically active and unique butenolide and hydrazulenone natural products from the three species of genus Hortonia (Ratnayake et al., 2001; Ratnayake et al., 2008a; Ratnayake et al., 2008b; Ratnayake et al., 2008c; Carr et al., 2012).

\section{MATERIALS AND METHODS}

\section{The plant material}

H. angustifolia was collected from Kanneliya and was identified by Dr. Siril Wijesundara, former Director Department of Botanic Gardens.

\section{Isolation of (4S)-4-methyl-2-(9-epoxy-11-dodecynyl)- 2-butenolide 1 and (4S)-4-methyl-2-((9Z)-11-epoxy-9- dodecenyl)-2-butenolide 2}

Air-dried, powdered leaves were repeatedly extracted with $\mathrm{CH}_{2} \mathrm{Cl}_{2}$ and dried in vacuo to obtain black oil. This crude extract was then subjected to repeated rounds of silica gel chromatography using $\mathrm{MeOH}-\mathrm{CH}_{2} \mathrm{Cl}_{2}(1: 99)$ as the eluent in a gradient of increasing polarity up to $\mathrm{MeOH}-\mathrm{CH}_{2} \mathrm{Cl}_{2}(1: 1)$, gave a fraction which was purified by flash chromatography with $\mathrm{CH}_{2} \mathrm{Cl}_{2}$-hexane (4:1) and $\mathrm{C}_{18}$ reversed-phase HPLC to yield compound 1 and 2 as colourless oils, $(0.06 \%$ and $0.87 \%$, respectively, with respect to leaf extract).

\section{RESULTS AND DISCUSSION}

Compound 1 gave $\left[\mathrm{M}^{+}\right]$at 276.1730 in its HREIMS suggesting that molecular formula of the compound 1 was $\mathrm{C}_{17} \mathrm{H}_{24} \mathrm{O}_{3}$. The IR spectrum of compound 1 showed an absorption at $2110 \mathrm{~cm}^{-1}$ indicating the presence of an ethynyl moiety, an $\alpha, \beta$-unsaturated $\gamma$-lactone carbonyl at $1755 \mathrm{~cm}^{-1}$ and unsaturation at $1680 \mathrm{~cm}^{-1}$. The absorption at $1270 \mathrm{~cm}^{-1}$ and $950 \mathrm{~cm}^{-1}$ indicated the presence of an epoxide moiety. The UV spectrum of compound 1 showed absorption at $\lambda_{\text {max }} 231 \mathrm{~nm}$ indicating that an $\alpha, \beta$-unsaturated $\gamma$-lactone moiety was present. 


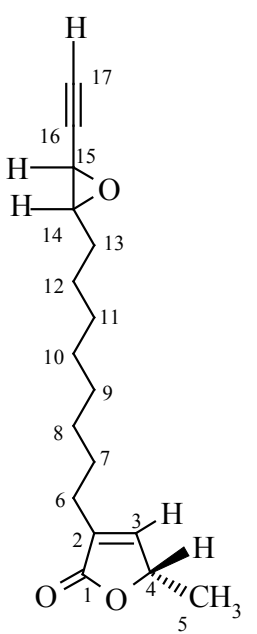

Compound 1

The UV absorption band at $231 \mathrm{~nm}$, the mass fragment peaks at $\mathrm{m} / \mathrm{z} 67(100 \%), 81(65 \%)$ and $95(88 \%)$ and the ${ }^{1} \mathrm{H}$ NMR signals at d 4.99 (H-4), $1.40(\mathrm{H}-5)$ and $6.99(\mathrm{H}-$ 3 ), confirmed the presence of an $\alpha, \beta$-unsaturated $\gamma$-lactone moiety. The ${ }^{1} \mathrm{H}$ and ${ }^{13} \mathrm{C}$ NMR data obtained for compound 1 (Table 1) showed 17 carbon resonances with 24 attached hydrogen atoms $\left(1 \mathrm{x} \mathrm{CH}_{3}, 8 \times \mathrm{CH}_{2}, 5 \times \mathrm{CH}, 3 \times \mathrm{C}\right)$. The resonances detected in ${ }^{13} \mathrm{C}$ NMR and APT spectrum indicated the presence of one ester carbonyl ( $\delta$ 173.9), two $\mathrm{sp}^{2}$ carbons $(\delta 134.2$ and 148.9), two sp carbons $(\delta$ 71.7 and 80.5 ), three oxygen substituted methines ( $\delta 44.8$, 57.9 and 60.3), eight methylenes ( $\delta 31.6,29.1,29.127 .3$, $25.8,25.5,25.1$, and 25.1$)$ and one methyl $(\delta$ 19.2). The presence of a carbonyl group $(\delta$ 173.9) and oxygenated methine carbon $(\delta 60.3)$ suggested an ester function. The molecular formula of $\mathrm{C}_{17} \mathrm{H}_{24} \mathrm{O}_{3}$ was established by HRMS and was fully consistent with the number of carbon centers detected in the ${ }^{13} \mathrm{C}$ NMR spectrum.

Five of the six degrees of unsaturation present were

Table 1: NMR spectroscopic data of epoxy butenolides 1 and 2.

\begin{tabular}{|c|c|c|c|c|c|c|}
\hline Carbon & $(1)^{13} \mathrm{C}$ & $(1)^{1} \mathbf{H}$ & $(1)^{1} \mathbf{H}-{ }^{1} \mathbf{H}$ & (2) ${ }^{13} \mathrm{C}$ & $(2)^{1} \mathbf{H}$ & $(2)^{1} \mathbf{H}-{ }^{1} \mathbf{H}$ \\
\hline 1 & 173.9 & & & 169.1 & & \\
\hline 2 & 134.2 & & & 129.7 & & \\
\hline 3 & 148.9 & $6.99 \mathrm{~d}(1.7)$ & 4,6 & 150.1 & $6.62 \mathrm{dt}(7.7,1.2)$ & 6 \\
\hline 4 & 60.3 & $4.99 \mathrm{dq}(6.8,1.7)$ & 3,5 & 77.7 & $4.60 \mathrm{~m}$ & 5 \\
\hline 5 & 19.2 & $1.40 \mathrm{~d}(6.8)$ & 4 & 14.5 & $1.43 \mathrm{~d}(6.6)$ & 4 \\
\hline 6 & 25.1 & 2.25 br t $(7.3)$ & 3,7 & 28.3 & $2.80 \mathrm{~m}$ & 3 \\
\hline 7 & 25.1 & $1.53 \mathrm{~m}$ & 6 & 29.0 & & \\
\hline 8 & 25.57 & & & 29.2 & & \\
\hline 9 & 25.8 & & & 29.4 & & \\
\hline 10 & 27.3 & $1.31 \mathrm{br} \mathrm{s}$ & & 29.6 & 1.38 br s & \\
\hline 11 & 29.1 & & & 29.6 & & \\
\hline 12 & 29.1 & & & 30.1 & & 13 \\
\hline 13 & $31.6-$ & & 14 & 30.6 & $2.38 \operatorname{tdd}(7.5,7.5,1.2)$ & $12,14,15$ \\
\hline 14 & 44.8 & $2.33 \mathrm{dt}(14.5,1.5)$ & $13,15,17$ & 146.6 & $6.05 \mathrm{dt}(10.8,7.5)$ & 13,15 \\
\hline 15 & 57.9 & $3.08 \mathrm{dd}$ & 14,17 & 108.4 & $5.50 \mathrm{dq}(10.8,1.2)$ & $13,14,17$ \\
\hline 16 & 71.7 & & & 71.8 & $4.72 \mathrm{~m}$ & \\
\hline 17 & 80.5 & $1.68 \mathrm{br} \mathrm{s}$ & 14,15 & 81.2 & $3.17 \mathrm{~d}(2.2)$ & 15 \\
\hline
\end{tabular}
unsaturation was assigned to an epoxide ring. presence of the epoxide group. (Martinez et al., 1981).

accounted for the ester carbonyl, a triple bond and an $\alpha, \beta$-unsaturated $\gamma$-lactone ring. The remaining degree of

Its ${ }^{1} \mathrm{H}$ NMR spectrum showed a broad singlet for twelve aliphatic methylene protons at $\delta 1.31(\mathrm{H}-8,9,10,11,12$, 13). The multiplet at $\delta 1.53$ and the broad triplet at $\delta 2.25(J$ $=7.3 \mathrm{~Hz}$ ) were assigned to $\mathrm{H}-7$ and $\mathrm{H}-6$, respectively. The down field ${ }^{1} \mathrm{H}$ and ${ }^{13} \mathrm{C}$ NMR resonances were assigned to the conjugated double bond in the $\gamma$-lactone ring $\left[\delta_{\mathrm{H}} 6.99\right.$, $1 \mathrm{H}, \mathrm{d}, J=1.7 \mathrm{~Hz}, \mathrm{H}-3,\left(\delta_{\mathrm{C}} 148.9\right.$ and 134.2)], an aliphatic methine residue attached to an oxygen atom $\left[\delta_{\mathrm{H}} 4.99, \mathrm{H}-4\right.$, $\left.\mathrm{dq}, J=6.8,1.7 \mathrm{~Hz},\left(\delta_{\mathrm{C}} 60.3\right)\right]$ and a $\gamma$-lactone carbonyl $(\delta$ 173.7). Additional ${ }^{1} \mathrm{H}$ and ${ }^{13} \mathrm{C}$ NMR resonances could be assigned to a terminal ethynyl group $\left[\delta_{\mathrm{H}} 1.68, \mathrm{H}-17\right.$, broad $\mathrm{s},\left(\delta_{\mathrm{C}} 80.5\right.$ and 71.7$\left.)\right]$, a secondary methyl group $\left[\delta_{\mathrm{H}} 1.40\right.$, $\left.3 \mathrm{H}, \mathrm{d}, J=6.8 \mathrm{~Hz}, \mathrm{H}-5,\left(\delta_{\mathrm{C}} 19.2\right)\right]$ and an epoxide moiety $\left[\delta_{\mathrm{H}} 2.33, \mathrm{dt}, J=14.5,1.5 \mathrm{~Hz}, \mathrm{H}-14,\left(\delta_{\mathrm{C}} 44.8\right), \delta_{\mathrm{H}} 3.08, \mathrm{dd}\right.$, $\left.\mathrm{H}-15,\left(\delta_{\mathrm{C}} 57.9\right)\right]$. The large coupling of $14.5 \mathrm{~Hz}$ between $\mathrm{H}-14$ and one of the protons attached to H-13 illustrated the rigidity in that area of the molecule introduced by the

The H-H COSY spectrum of compound 1 showed coupling between $\delta 3.08(\mathrm{H}-15)$ and $(\mathrm{H}-14)$ of the epoxide ring. In addition the $\mathrm{H}-\mathrm{H}$ COSY spectrum showed both $\mathrm{H}-15(\delta 3.08, \mathrm{dd})$ and H-14 $(\delta 2.33$, dt) HMBC correlation with $\mathrm{H}-17$ ( $\delta 1.68$, broad s) indicating that epoxide moiety was attached to the ethynyl group. The coupling observed between C-5 methyl doublet $(\delta 1.40, \mathrm{~d}, J=6.8 \mathrm{~Hz})$ and $\mathrm{H}-4$ ( $\delta$ 4.99, dq, $J=6.8,1.7 \mathrm{~Hz}$ ) established that C-5 methyl is attached to $\mathrm{C}-4$ of the $\gamma$-lactone ring. The C-6 methylene protons which coupled to H-3 ( $\delta 6.99$, d, $J=$ $1.7 \mathrm{~Hz})$ also correlated to $\mathrm{H}-7(\delta 1.53, \mathrm{~m})$ suggesting that $12 \mathrm{C}$ atoms containing side chain was situated at $\mathrm{C}-2$. With a negative optical rotation literature precedent indicated that the absolute configuration of compound 1 at C-4 was $S$ 
Compound 1 was found to be inactive against the $2^{\text {nd }}$ instar larvae of Aedes aegypti at $10 \mathrm{ppm}$ (Bandara et al., 2000).

\section{(4S)-4-methyl-2-((9Z)-11-epoxy-9-dodecenyl)-2- butenolide}

Compound 2 showed a molecular ion $\left[\mathrm{M}^{+}\right]$at 278.0456 in its HREIMS suggesting that the molecular formula of compound 2 is $\mathrm{C}_{17} \mathrm{H}_{26} \mathrm{O}_{3}$. The IR spectrum of compound 2 exhibited frequencies corresponding to $\alpha, \beta$-unsaturated$\gamma$-lactone carbonyl at $1730 \mathrm{~cm}^{-1}$ and unsaturation at 1670 $\mathrm{cm}^{-1}$. The absorption at $1175 \mathrm{~cm}^{-1}$ and $1040 \mathrm{~cm}^{-1}$ indicated the presence of an epoxide moiety ${ }^{52}$. The UV spectrum of compound 2 showed an absorption at $\lambda_{\max } 244 \mathrm{~nm}$ indicating that an $\alpha, \beta$-unsaturated- $\gamma$-lactone moiety was present. Furthermore, the fragments which appeared in the low resolution mass spectrum of compound $2[\mathrm{~m} / \mathrm{z}$ $67(66 \%), 81(100 \%)$ and $95(71 \%)]$ along with the three characteristic ${ }^{1} \mathrm{H}$ NMR signals at $\delta 4.60(\mathrm{H}-4), 1.43(\mathrm{H}-$ 5) and 6.62 (H-3), also suggested the presence of an $\alpha$, $\beta$-unsaturated $\gamma$-lactone moiety.

The ${ }^{1} \mathrm{H} /{ }^{13} \mathrm{C} / \mathrm{APT}$ spectra obtained for compound 2 showed 17 carbons resonance with 26 attached hydrogen atoms $\left(1 \times \mathrm{CH}_{3}, 9 \times \mathrm{CH}_{2}, 5 \times \mathrm{CH}, 2 \times \mathrm{C}\right)$. The resonances detected in ${ }^{13} \mathrm{C}$ NMR and APT spectra indicated the presence of one ester carbonyl ( $\delta 169.1)$, four $\mathrm{sp}^{2}$ carbons $(\delta 150.1$, $146.6,129.7$ and 108.4), two oxygen substituted methines and one oxygen substituted methylene $(\delta 77.7$ and 71.8 and 81.2), eight methylenes $(28.3,29.0,29.2,29.4,29.6,29.6$, 30.1 and 30.6) and one methyl group $(\delta 14.5)$. The presence of a carbonyl group at $(\delta 169.1)$ and oxygenated methine carbon $(\delta 77.7)$ suggested an ester function.

Molecular formula of $\mathrm{C}_{17} \mathrm{H}_{26} \mathrm{O}_{3}$ was established by HREIMS and was fully consistent with the number of carbon centers detected in the ${ }^{13} \mathrm{C}$ NMR spectrum. Four of the five degrees of unsaturation present were accounted for by the ester carbonyl, a double bond, an $\alpha, \beta$-unsaturated $\gamma$-lactone ring. The remaining degree of unsaturation was assigned to an epoxide ring.

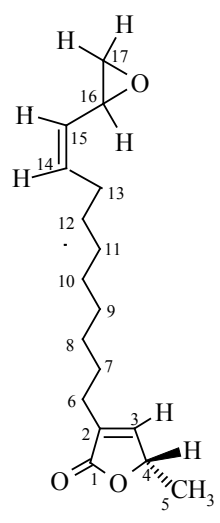

Compound 2
Its ${ }^{1} \mathrm{H}$ NMR spectrum showed broad singlet for twelve aliphatic methylene protons at $\delta \sim 1.38(\mathrm{H}-7,8,9,10,11$ and 12). A doublet of a tripletat $\delta 2.38$ was assigned to $\mathrm{H}-13(2 \mathrm{H}$, $J=7.5,1.2 \mathrm{~Hz}$ ) and the HMBC spectrum showed coupling to the adjacent methylene group H-12 $(J=7.5 \mathrm{~Hz})$, and allylic coupling to the olefinic protons $\mathrm{H}-14(J=7.5 \mathrm{~Hz})$ and $\mathrm{H}-15(J=1.2 \mathrm{~Hz})$. The appearance of a multiplet at $\delta$ 2.80 was due to $\mathrm{H}-6 .{ }^{1} \mathrm{H}$ and ${ }^{13} \mathrm{C}$ NMR resonances could be assigned to a terminal epoxide moiety $\left[\delta_{\mathrm{H}} 3.17,2 \mathrm{H}, \mathrm{d}, J=\right.$ $2.2 \mathrm{~Hz} ; 4.72,1 \mathrm{H}, \mathrm{m},\left(\delta_{\mathrm{C}} 81.2\right.$ and71.8)]. This epoxide in turn was attached to a cis-double bond $(\mathrm{C}-14,15)\left[\delta_{\mathrm{H}} 5.50, \mathrm{dq}\right.$, $J=10.8,1.2 \mathrm{~Hz}, \mathrm{H}-15 ; \delta_{\mathrm{H}} 6.05, \mathrm{dt}, J=10.8,7.5 \mathrm{~Hz}, \mathrm{H}-14$ $\left(\delta_{\mathrm{C}} 146.6\right.$ and 108.4) and secondary methyl group $\left[\delta_{\mathrm{H}} 1.43\right.$, $\left.\mathrm{d}, J=6.6 \mathrm{~Hz},\left(\delta_{\mathrm{C}} 14.5\right)\right]$. The presence of a cis-double bond in compound 2 was further substantiated by the absence of a $700-900 \mathrm{~cm}^{-1}$ IR absorption that is characteristic of trans double bonds. There is ample literature precedent for the occurrence of cis-double bonds in acetogenin side chains. Similar to previously reported butenolides (Ratnayake et al., 2001) in 2 the down field ${ }^{1} \mathrm{H}$ and ${ }^{13} \mathrm{C}$ NMR resonances were assigned to a double bond $\left[\delta_{\mathrm{H}} 6.62, \mathrm{dt}, J=7.7,1.2 \mathrm{~Hz}\right.$, $\mathrm{H}-3,\left(\delta_{\mathrm{C}} 129.7\right.$ and 150.1)], an aliphatic methine residue attached to an oxygen atom $\left[\delta_{\mathrm{H}} 4.60, \mathrm{~m}, \mathrm{H}-4\left(\delta_{\mathrm{C}} 77.7\right)\right]$ and a $\gamma$-lactone carbonyl ( $\delta$ 169.1).

The H-H COSY spectrum of compound 2 showed coupling between $\delta 3.17(\mathrm{H}-17)$ and $\delta 5.50(\mathrm{H}-15)$ in addition to correlation between $\delta 5.50(\mathrm{H}-15)$ and $\delta 6.05$ (H-14) indicating that epoxide moiety was attached to a double bond moiety. The presence of only two olefinic protons along with three epoxy protons confirmed that it was the epoxide group which was terminal and not the double bond. The coupling observed between H-15 ( $\delta$

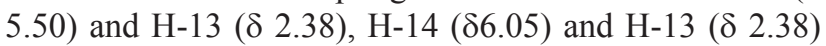
indicated that the cis-double bond was attached to C-13. The correlation between C-5 methyl doublet $(\delta 1.43)$ and $\mathrm{H}-4(\delta 4.60, \mathrm{~m})$ established that C-5 methyl is attached to $\mathrm{C}-4$ of the $\gamma$-lactone ring. The COSY spectrum further showed that C-6 methylene protons $(\delta 2.80, \mathrm{~m})$ were coupled to $\mathrm{H}-3$ ( $\delta$ 6.62) suggesting that $\mathrm{C}_{12}$ side chain was situated at C-2.

With a negative optical rotation literature precedent indicated that the absolute configuration of compound 2 at C-4 was $S$ (Martinez et al., 1981). Compound 2 exhibited moderate mosquito larvicidal activity at $10 \mathrm{ppm}\left(\mathrm{LC}_{50}=\right.$ 7.87).

\section{REFERENCES}

Bandara, B.M.R., Hewage, C.M., Jayammane, L., Karunaratne, V., Bandara, K.A.N.P., Adikaram, N.K.B., Pinto, M.R.M. and Wijesundara, D.S.A. 1990. Biological activity of some steam distillates from ten species of Rutaceae plants, Journal of the National Science Council of Sri Lanka 18(1): 71-77.

Bandara, K.A.N.P., Kumar, V., Jacobson, U. and Molleyres, L.P. (2000). Insecticidal piperine alkaloid from Microscos paniculata stem bark. Phytochemistry 54: 29-32.

Carr, G., Ratnayake, R., Bandara, R., Wijesundara, S., Williams, D.E., Tarling, T., Balgi, A.D., Roberge, M., Karunaratne, V. and Andersen, R.J. (2012). 
Hydrazulenones from the genus Hortonia. Journal of Natural Products 75(6): 1189-1191.

Dassanayake M.D. (1996). A Revised Handbook to the Flora of Ceylon, Volume X; Oxford \& IBH Publishing Co. Pvt. Ltd., New Delhi, pp. 282-285.

Hewage, C.M., Bandara, K.N.A.P; Karunaratne, V; Bandara, B.M.R., andWijesundara, D.S.A. (1997). Insecticidal activity of some medicinal plants of Sri Lanka, Journal of National Science Council of Sri Lanka 25(3): 141-150.

Jayasekara R. (1997). Arjuna's Atlas of Sri Lanka. (Eds. T. Somasekaram. M.P. Perera, M.B.G. de Silva \& H. Godellawatte. Arjuna Consulting Co. Ltd., Dehiwala, pp 36.

Karunaratne, V., Hoveyda, H.R. and Orvig, C. (1992). General method for the Synthesis of Trishydroxamic acids. Tetrahedron Letters 33: 1827-1830.

Karunaratne, V., Bombuwala, K., kathirgamanathar, S. and Thadani, V. (2005). Lichens: A chemically important biota. Journal of National Science Foundation Sri Lanka 33(3): 169-186.

Kathirgamanathar, S., Ratnasooriya, W.D., Baekstrom, P., Andersen, R.J. and Karunaratne, V. (2006). Chemistry and bioactivity of physciaceae lichens: Pyxine consocians and Heterodermia Leucomelos. Pharmaceutical Biology 44: 217-220.

Martinez, V.J.C., Yoshida, M. and Gottlieb, O.R. (1981). Omega-ethyl, omega-ethenyl and omega-ethynylalpha-alkylidene-gamma-lactones from Clinostemon mahuba. Phytochemistry 20: 459-464.

Orange, A., Wolseley, P., Karunaratne, V. and Bombuwela, K. (2001). Two Leprarioid Lichens New to Sri Lanka. Bibliotheca Lichenologica 78: 327-333.

Piers, E. and Karunaratne V. (1984). Methylenecyclopentane annulation: a synthesis of the sesquiterpenoid ( \pm )-pentalenene. Journal of the Chemical Society, Chemical Communications 15: 959-960.

Puvenendran, S., Carr, G., Wickramasinghe, A., Karunaratne, D.N., Andersen, R.J. and Karunaratne, V. (2008). Antioxidant constituents of Xylopia championii. Pharmaceutical Biology 46: 252-256.

Ratnayake, R., Karunaratne, V., Ratnayake Bandara, B.M., Kumar, V., MacLeod, J.K. and Simmonds, P. (2001). Two new lactones with mosquito larvicidal activity from three Hortonia species. Journal of Natural Products 64: 376-378.

Ratnayake, R., Bandara, B.M., Wiesundara, D.S.A., Carr, G., Andersen, R.J. and Karunaratne, V. (2008). Four butanolides derivatives from Hortonia, a genus endemic to Sri Lanka. Journal of Chemical Research 3: 134-136.

Ratnayake, R., Jayasinghe, S., Andersen, R.J. and Karunaratne, V. (2008b). Complete 2-D assignement and antifungal activity of Ishwarane isolated from the genus Hortonia.J. National Science Foundation of Sri Lanka 36(1): 109-122.

Ratnayake, R., Bandara, B.M.R., Wijesundara, D.S.A., MacLeod, J.K., Simmonds, P. and Karunaratne, V. (2008). Chemistry and bioactivity of the genus Hortonia. Natural Products Research 22: 1393-1402.

Tezuka, Y., Kikuchi, T., Dhanabalasingham, B., Karunaratne, V. and Gunatilaka, A.A.L. (1994). Studies on Terpenoids and Steroids, Part 25. Complete ${ }^{\mathrm{I}} \mathrm{H}$ and ${ }^{13} \mathrm{C}$ NMR assignments of Salaciquinone, A new 7-Oxo-Quinonemethide dinortriterpenoid from Salacia reticulata. Journal of Natural Products 57(2): 270-276.

Thadhani, V.M., Choudhary, I. and Karunaratne, V. (2012). Antimicrobial activity and cytotoxicity of lichen metabolites. Journal of National Science Foundation of Sri Lanka 40(1): 43-48. 